\title{
The Critical Discourse Analysis of The Representation of Women And Men in Bozorg Alavi's Short Stories
}

\author{
Nasser Rashidi (corresponding author) \\ Shiraz University \\ E-mail: naser.rashidi@shirazu.ac.ir \\ Alireza Khormaei \\ Shiraz University \\ E-mail: akhormaee@rose.shirazu.ac.ir \\ Maryam Zarei \\ Shiraz University \\ E-mail: zarei_maryam@ymail.com
}

Doi:10.7575/aiac.alls.v.5n.3p.126

URL: http://dx.doi.org/10.7575/aiac.alls.v.5n.3p.126
Received: $1104 / 2014$

Accepted: 15/05/2014

\begin{abstract}
This study takes a critical discourse analysis approach to the investigation of the representation of men and women in Bozorg Alavi's short stories. The principal aim of this study is to find how different statuses of men and women are reflected in their languages. To this end, four short stories were selected and their discursive sentences were examined based on Hodge and Kress's syntagmatic models, which comprise actionals vs. relationals features. The results of this study show that men have higher status than women do in these stories.
\end{abstract}

Key words: critical discourse analysis, discursive structures, language ideology, social status

\section{Introduction}

Discourse analysis (DA) is a general term for a number of approaches to analyzing written, spoken, signed language use or any significant semiotic event.

The objects of discourse analysis are variously defined in terms of coherent sequences of sentences, propositions, speech acts or turns-at-talk. Contrary to much of traditional linguistics, discourse analysts not only study language use 'beyond the sentence boundary', but also prefer to analyze 'naturally occurring' language use, and not invented examples. Discourse analysis has been taken up in a variety of social science disciplines, including linguistics, sociology, anthropology, social work, cognitive psychology, social psychology, international relations, human geography, communication studies and translation studies, each of which is subject to its own assumptions, dimensions of analysis, and methodologies.

Yarmohammadi, 1385 notes:

In discourse analysis, the relation between discursive structures and social ideologies governing the production of discourse is studied and described. The discursive structures are linguistic, historical, and sociological elements that reflect particular social ideologies. (p.38)

Discourse analysis has two approaches: descriptive and critical approach. Critical discourse analysis (CDA) as its name suggests, is analyzing discourse critically.

Yarmohammadi (1383:4) defines critical discourse analysis as "a kind of discourse analysis which studies the unlawful use of power, dominance and inequality that happen in a social and political context through speech and writing".

Fairclough (1993: 135) in his definition perceives CDA as:

discourse analysis which aims to systematically explore often opaque relationships of causality and determination between (a) discursive practice, events and texts, and (b) wider social and cultural structures, relations and processes; to investigate how such practices, events and texts arise out of and are ideologically shaped by relations of power and struggles over power; and to explore how the opacity of these relationships between discourse and society is itself a factor securing power and hegemony. 
Van Dijk, 1998 argues:

Critical discourse analysis is a type of discourse analytical research that primarily studies the way social power abuse, dominance and inequality are enacted, reproduced and resisted by text and talk in the social and political context; with such dissident expose and ultimately to resist social inequality. (p.45)

The importance of ideology is often emphasized in CDA. Agha Golzadeh (2007) notes that in critical linguistics, the purpose of analysis is not to discover complicated and unusual meanings in the text, but to clear the process of articulation and perception, which enables the analysts to observe the work of ideology in the language and introduce it to others.

Hodge and Kress (1996) state that the reality expressed through language is not something like the original reality perceived by the speaker or writer. They believe that we perceive whatever we expect from the world. Boutain (1999: 7) believes that "a pragmatic view of language and a critical study of discourse join the study of language to the study of society". Thus, it can be claimed that our perception of the reality is socially constructed by language.

Dellinger (1995:3) believes:

"the mode in which an action is presented, either as transactive or nontransactive, is not a matter of truth or reality but rather a matter of the way in which that particular action is integrated into the ideological system of the speaker, and the manner in which such an action is therefore articulated in a specific discourse"

Thus, socially constructed reality may be quite different from the reality itself depending on how the speaker or writer perceives and represents it. Hodge and Kress (1996) consider this perception as ideology. Therefore, the words used by the speaker are by no means accidental, since he chooses them out of several different options available in the language. In this sense that language can be considered as ideology (Hodge and Kress, 1996)

Many researchers have studied different areas based on critical discourse analysis. In politics, we can mention Deghat (2008), Horvath (2009), Benoit and Henson (2009), Easter (2008). They all have studied the speeches of American presidents and shown the strategies used in their speeches based on critical discourse analysis.

Mohasel Bashough (2003), Davatgarzadeh (2007), Asgharzadeh (2009), Amalsaleh (2004), Brantmier (2003), and Otlowski (2003) have done critical studies on language learning textbooks. In all these studies the main objective is to find out how the representations, used in the texts construct certain social and normative realities, such as subjectivity and identity.

Ideology is all the time emphasized in journalism. The ways ideologies are represented or even hidden are studied in most of the studies on journalism. Khosravi Nik (2000), Yarmohammadi and Rashidi (2003), Hawes et al. (1996), Li (2010), and Galasiski and Marley (1997) have tried to show the relations between choices of certain linguistic forms and the ideologies and power relations which underlie such forms.

Studies on literal texts are mostly done on stories. In these stories gender, age, and class are of great importance. One example of age consideration is that of Foziyeh's (2004). It shows how certain discursive features manipulated the representation of certain ideologies in children's and adults' stories. Norouzi (2006), Smith (2002), and Hobson's (2003) studies are examples of gender consideration. It seems that most of the studies related to gender have feministic color. The studies attempt to prove women's bad condition and their lack of support from the society. Finally, as an example for class consideration, we can mention Collins' (1999) study. He critically reviews Huspek's work and suggests ways in which, through critique, we might further the project of an emancipatory linguistics.

The current research investigates the relation between discursive structures and underlying ideologies in men and women speeches in four short stories of Bozorg Alavi, based on Hodge and Kress's syntagmatic models. No research has been done on women characters vs. men characters based on these models and this study is the first to compare women and men's statuses.

\subsection{Objective of the study and research questions}

In this paper, an attempt has been made to analyze four short stories of Bozorg Alavi, the great Iranian author. In fact, the present study aims at studying men and women's use of language in Bozorg Alavi's short stories to investigate whether their languages imply their different social status.

Based on the objective of the research, there arise the following questions:

1 - Do men and women have the same social status as reflected in their languages in these stories?

2- If the answer to the previous question is negative, how this difference can be recognized linguistically? 


\section{Methodology}

\subsection{Corpus}

Four short stories by Bozorg Alavi, taken randomly, comprised the corpus of the story. These short stories are Chamadan (the suitcase), ?jare xane (house rent), qorbani (victim) and sarbaz-e sorbi (leaden soldier).

\subsection{Procedure}

Each short story is studied for discursive structures uttered in the texts, reflecting special linguistic features, i.e. grammatical items. These special items are chosen and analyzed to investigate and compare the status of men and women.

\subsection{Theoretical Framework}

In the analysis of how the statuses of men and women are represented, the study has applied Hodge and Kress's (1996) syntagmatic models. According to their models, a text is critically analyzed with respect to two features i.e., actionals vs. relationals each containing two subtypes as shown below:

$$
\text { Syntagmatic models }\left\{\begin{array}{c}
\text { actionals }\left\{\begin{array}{l}
\text { transactive } \\
\text { non-transactive }
\end{array}\right. \\
\text { relationals }\left\{\begin{array}{l}
\text { equative } \\
\text { attributive }
\end{array}\right.
\end{array}\right.
$$

Figure 1. Syntagmatic Models (Hodge and Kress,1996, p.9)

In the first model, there are two entities related by a process, one of the two is the cause of the action and the other is affected by it. Here the action is passing through the actor to the affected. This model is called transactive model. In the sentence Ali killed Reza, he action of killing passes from the actor Ali to the affected Reza.

In the second model, there is minimally one entity related to a process. Because there is only one entity, it is not clear whether it is the cause or the affected. This model is called non-transactive model. In the sentence Ali walks, we have the process of walking and just one entity Ali whose status is not clear. Ali is not the actor since he does not initiate or cause the process walks. Nor is it the affected. Ali is simply involved in the process though it is not clear in what way.

The transactive and non-transactive are both about action and they are called actional models or actionals.

The third model involves not an action or process but a simple relation between two entities or nouns. This model is called equative model. For example, in the sentence Ali is the cleverest student, there is an equality relation between Ali and the cleverest student. In another word, one can say Ali and the cleverest student are the same or equal.

The last model shows a relation between an entity and a quality and it is called attributive model. The sentence Ali is clever is a simple example.

Equative and attributive models are called relational models or just relationals.

\section{Results and Discussion}

\subsection{Short story 1. Chamadan (suitcase)}

In the short story "Chæmædan" (the suitcase), the quarrel between two generations, the son and the father is reflected. The father is disciplined and rich but the son is not. Therefore, it is clear that they do not go along with each other. The son has encountered a beautiful Russian girl, called Katoushka. She wants to go to Sito and marry there. The father wants to go to Sito too and the boy accompanies him unwillingly. Katoushka and the son visit each other and have a romantic time together. Katoushka asks the son to introduce his father to her and to come and visit her future husband. When he goes to visit her and her husband, he finds his father next to her. He sends her a message in which he has written: "you wanted me to introduce my father to you, he's the one next to you, and he's going to be a good husband for you."

\subsubsection{Ideological background}

The author tries to show that 'man' is the sole power at home, the commander whom all must obey. Men do not trust women easily as they call women liars. Men in this story consider all women to be the same and it seems to be hard for them to confess women's positive points.

The man is considered as the one who forgets his love while the woman would not forget her love. The woman does not consider the man's love as genuine. She knows his love would stop soon yet she adores the love and finds it as something she would live with forever. 


\subsubsection{Analysis and discursive structures}

"pedær khoda-ye xane ?æst" (Father is the god of the house) (p.8, para 4)

This is a relational and equative sentence in which 'pedær' (father) is equal to the god or boss of the house which shows the importance of the father or man at home.

"belæxære hæme-ye zænha yeki hæstænd" (Anyway, all women are the same) (p.12, para 4)

This sentence is relational and attributive. The man is judging women negatively.

"gery-e ?anha doruq, xænde-ye ?anha doruq!" (Their crying is lie and their laughing is lie), "?ægær katushka doruqgu ?æst pæs hæmey-e zænha doruqgu hæstænd" (If Katoushka is a liar, so all women are liars) (p.12, para 4)

The first two sentences are equative and the next two sentences are attributive. They are all uttered by men about women.

“?ehsasat-e doruq nædasht" (She didn't have false feelings) (p.14, para 5)

A positive attribute is given to women through this relational and attributive sentence.

"zænha hæme xod-ra miforushænd" (All women sell themselves) (p.16, para 1)

This is an actional and transactive sentence in which the agent and the affected are both the same (women). Using this structure, the speaker shows a kind of crime committed by women themselves and finds women faulty and searches for no other factors involved. In addition, it shows that men consider themselves as those who can buy women and so find themselves more powerful and as the owners.

"to chetowr mitævani ?omri ba mæn be sær bebæri?" (How can you get along with me all your life?) (p.15, para 1)

This is an actional non-transactive in which the man is the actor. The woman considers herself to be in a lower position.

"to nemitævani showhær-e mæn shævi" (You can not get married with me) (p.15, para 1)

The sentence is actional transactive in which the man is the actor and the woman is the affected. Here again the woman finds herself in a lower position.

There are three actionals among which two are transactive and one is non-transactive. In one of the transactive sentences, the woman is the actor and in another the man is. The man is also the actor in non-transactive sentence. There are seven relationals among which three are equative from which one is about men and two are about women. Four of the relationals are attributive and about women. Thus, most of the relationals are about women. This fact shows that women have a kind of fixed and static position, which reveals their lower status. In contrast, men do not have static positions, they are actors most of the times, and therefore, they are higher in status.

\subsection{Short story 2. ?ejare xane (house rent)}

?ejare xane is the description of misery and poverty of the families that are wandering in the shantytown. Alavi takes the reader to the depth of the society in this story, where the struggle for surviving and continuing a sort of plant-like life can be seen.

Seyyed Mosæyyeb lives with his wife Xeironesa and his daughter in a rented room. Zæn Agha, his neighbor insists that his young daughter who has become a teacher recently marry a driver because people say bad things about a mature girl who has not married. The roof of their room is in a bad condition and it must be repaired. Seyyed Mosæyyeb is worried about the roof but he cannot afford it. One night when they have slept, the roof falls down on the family and kills them.

\subsubsection{Ideological background}

The discursive sentences in this short story disclose the fact that men do not respect women and insult them easily. They consider all women to be the same and regard them as serious diseases, which annoy them. It seems that men deem women unhappy lives. Women think that marriage is very important. They believe that being ingenious and educated is not valuable if a girl is single.

\subsubsection{Analysis and discursive structures}

"mæhz-e xater-e shoma zæn jæma?æt, ?adæm cheqæd bayæd dær ?in donya mokafat bebine?" (For the sake of you women, how much a man must be punished in this world?) (p.102, para 2)

This sentence is actional non-transactive in which the man is the actor and the affected and the woman is stated as the real cause in a separate unit at the beginning of the sentence.

"vay bær væjihe" (Woe is Vajihe) (p.104, para 1)

This sentence is relational and attributive* in which the woman deserves pity and this shows that the man is foreseeing a dark future for the girl. It also indicates that men do not consider women to become lucky or successful in their lives and in this way the low status and position of women in the society is shown.

* Although the translation is equative, the basis of our analysis is the original Persian discourse which is attributive.

"doxtær-e shoma ?æz hær ?ængosht-esh honær mirize" (Your daughter is ingenious). (p.98, para 2)

This sentence is an idiom. The literal meaning of this sentence is something like 'each finger of your daughter represents a skill'. However, since we cannot interpret an idiom word by word and its meaning is considered in whole, the sentence is considered relational and attributive as its meaning and not its structure suggests. 
"?adæm bæd-e doxtær be ?in bozorgi ro bi-showhær bezare" (It's bad to leave such a mature girl single) (p.98, para 2)

The second sentence is actional transactive in which the actor can be either the man or the woman. However, the woman is addressing her husband and actually, the man is the actor. Nevertheless, what is important here is the affected that is the girl.

"doxtær be ?in bozorgi ro bi-showhær bezare sobh ta shum ke tu kucheha vel bashe" (Leave such a mature girl single so that she wanders in the streets from morning till night) (p.98, para 2)

The first sentence is actional and transactive in which the man is the actor and the woman is the affected while the second sentence is relational and attributive with negative connotation. (Although the English translation of the sentence is actional, we consider it as relational since the original Persian discourse is important for analysis. This is true throughout the whole article)

“miyam ye lægæd mizænæm bæsateto behæm mizænæm.” (I kick your layout and shatter it) (p.102, para 2)

The second sentence "ye lægæd mizænæm" (I kick) is actional and transactive in which the man is the actor. The last sentence "bæsateto behæm mizænæm" (I shatter your layout), is actional and transactive in which the man is the actor and the woman is the affected.

There are six examples of actionals among which five are transactive and one non-transactive. In all transactive sentences, men are the actors and in non-transactive the woman is. There are two relationals, which are about women. One is attributive and one is equative. Therefore, men are most of the times the actors while women have fixed and static positions. This shows that men have higher positions while women do not. Men are so powerful that can act frequently and never have static positions while women do not have any chance for the action.

\subsection{Short story 3. qorbani (victim)}

Ghorbani is a story of a young educated man Xosrow, who has tuberculosis and is to die, but he is eager to live. A young woman, called Foruq is in love with him. Xosrow plans to marry Foruq and sacrifices her. Foruq is very shy and from a good family. She knows that Xosrow is very bad-tempered at home, yet she convinces herself that he will be nice to his wife. She loves Xosrow and at last marries him. They go to seashore for their honeymoon. Xosrow drowns himself and after one year, Foruq dies because of the tuberculosis.

\subsubsection{Ideological background}

This story puts a man and a woman in contrast to each other. While the man is very self-confident and proud, the woman is shy and clumsy. The man does not love the woman while she adores him. The man considers the woman as a sheep and he finds her a good subject of laughing at but the woman respects the man and finds him worthy. The man seems to have only sexual desire to the woman and it is not important for him what happens to her.

\subsubsection{Analysis and discursive structures}

"felan kæs zændar shode, sængin-o rængin shode." (Somebody has adopted a wife and become sedate) (p.24, para 1)

Both sentences are relational, attributive and about the man.

"hich kodam ?æz ma ra dær ?otaqæsh rah nemidad" (He allowed none of us to enter his room) (p.25, para5)

This is an actional transactive sentence in which Xosrow is the actor and his family (including the woman) is the affected.

"foruq dæstpache bud" (Foruq was antsy) (p.28, para2)

The sentence is relational and attributive. The woman is given a negative static attribute by the man.

"foruq bekolli xejalætzædeh neshæste bud" (Foruq was sitting quite blushed) (p.29, para 1)

This is an actional non-transactive sentence in which the woman is both the actor and the affected.

"foruq-e bichare ?æz in jævab-e namonaseb kæmi sorx shod” (Poor Foruq became red by this unsuitable answer) (p.30, para 1)

This relational attributive sentence again shows the static and thus lower position of the woman.

"baz hædæfi bæray-e mæsxæregihay-e yek mah bæædæsh peida kærde bud" (He had found another aim for his coming month's foolery) (p.29, para 1)

This sentence is actional and transactive in which the man is the actor and Foruq is the affected.

"?aqa bebæxshid ?inja mærqum færmudid" (Excuse me sir. You have written here) (p.29, para 2)

Both sentences are actional non-transactive in which the man is the actor.

There are five examples of actionals from which two are transactive, and three are non-transactive. In transactive sentences, the actors are all men. In two of the non-transactives, men are actors and in one women. Thus, in most cases it is men who are the actors. There are four attributive relationals among which two are about men and two about women. As men are most of the times the actors and women those with fixed status, it is clear that men have higher positions while women have lower positions. Women can not be powerful when they are not the actors and have fixed status. 
3.4 Short story 4. scerbaz-e sorbi (leaden soldier)

It is a story about Mr. F., the fired clerk of the Opium Restriction Administration. On his trip to Bushehr, he gets familiar with a woman called Kowkæb and takes her to his house. Kowkæb is a prostitute and wanders at streets. She has no place to go and so Mr. F. can be a good chance for her.

Mr. F. ignores all his official letters and gets fired. To spend his life with Kowkæb, he makes leaden soldiers and sells them.

The story of the leaden soldier is written with a Freudian view; as Mr. F. has tendency towards his mother. Mr. F. is psychologically sick. He beats and insults Kowkæb. One day Kowkæb disappears and Mr. F. leaves Bushehr for Tehran and sees her again. Kowkæb escapes another time and finally, in his last meeting with Kowkæb, he kills her.

\subsubsection{Ideological background}

The author tries to show that the man is only happy with the memories of his mother and keeps a woman in his house to imagine that his mother is there. Although the woman does all his housework in order to stay there and not to wander in the streets, he beats her, insults her, etc. The woman hates him too and insults him when talking to his friend. There is no trust among them. Both hate each other but want to stay together. Both find each other guilty for their problems and miseries.

\subsubsection{Analysis and discursive structures}

"hærvæqt ?in zæn vared-e zendegani-ye mæn shod ?owza-e mæ ra bær hæm zæd." (Whenever this woman enters my life, it gets worse) (p.79, para 1)

This sentence is an actioanl transactive sentence in which the actor is the woman.

“mæra kosht." (She killed me) (p.81, para 1)

This sentence is actional transactive in which the actor is Kowkæb and the affected is Mr. F.

"mæn xial mikærdæm madæræm ?æst væ be hæmin xial xosh budæm." (I thought she was my mother and I was pleased with the idea) (p.81, para 2)

The first sentence is actional and non-transactive in which the man is the actor. Two other sentences are both relational. The first relational sentece (madæræm ?æst) is equative and about Kowkæb. The second relational (be hæmin xial xosh budæm) is attributive, and about the man.

“dær hær suræt ?u bæray-e mæn morde ?æst.” (Anyway she is dead for me) (p.85, para 1)

This sentence is relational attributive and about the woman.

"? in chador siya-ha ke dær kenar-e kucheha dær særma be divar chasbideænd, mesl-e xun-e dælæme shode ru-ye divar hæstænd." (These women with black scarves who stick to the walls in the cold are like the clot of blood) (p.89, para 1)

The first sentence which is about the woman is actional non-transactive. The sencond one is relational attributive and about the woman too.

“cheqædr mæn zæhmæt-o mælalæt ?æz dæst-e ?in keshideæm” (How much pain and discomfort I faced because of him) (p.90, para2)

This is an actional non-transactive sentence in which Kowkæb is both the actor and the affected.

"fohshæm midad, mæn-o mizæd, gisha-ye mæn-o mikænd, yek ruz mæn-o ?anqæd ba chub zæd ke ?æz hal ræftæm." (He insulted me, beat me, pulled my hair, one day he beat me with a piece of wood that I fainted) (p.92, para 2)

All the sentences are actionals and transactive except the last sentence (?æz hal ræftæm) which is non-transactive. In all the transactive sentences, the actor is the man and the affected is the woman. In non-transactive sentence, the actor is the woman.

There are eight examples of actionals from which five are transactive and three are non-transactive. Among the transactives, three of the actions are done by men and two are done by women. In non-transactives, all the actions are done by women except one which is done by men. Although most of the actions are done by women, those actions with certain affected (women) are done by men. Most of the actions done by women are without any affected or the affected is women themselves and not men. This shows that men are more powerful than women as they are the actors with the affected most of the times but women are not.

There are four examples of relationals among which one is equative and about women and three are attributive among which one is about men and two are about women. Since most of the relationals are about women, we can conclude that women have static and fixed position and as a result lower status. 
In four short stories, there are twenty two instances of actionals among which fourteen are transactive and eight are nontransactive. In transactives, eleven actions are done by men and three by women and in non-transactives, three actions are done by men and five by women. There are seventeen examples of relationals among which five are equatives and twelve are attributives. From equatives, one is about men and four about women and from attributives, three are about men and four about women.

Table 1. Frequency of the occurrences of actionals vs. relatioanls

\begin{tabular}{|c|c|c|}
\hline \multirow{4}{*}{$\begin{array}{l}\text { Actionals } \\
\quad 22\end{array}$} & \multirow{2}{*}{$\begin{array}{c}\text { Transactives } \\
14\end{array}$} & 11 men \\
\hline & & 3 women \\
\hline & \multirow{2}{*}{$\begin{array}{c}\text { Non-transactives } \\
8\end{array}$} & 3 men \\
\hline & & 5 women \\
\hline \multirow{4}{*}{$\begin{array}{c}\text { Relationals } \\
17\end{array}$} & \multirow{2}{*}{$\begin{array}{c}\text { Equatives } \\
5\end{array}$} & 1 men \\
\hline & & 4 women \\
\hline & \multirow{2}{*}{$\begin{array}{c}\text { Attributives } \\
12\end{array}$} & 3 men \\
\hline & & 9 women \\
\hline
\end{tabular}

Thus, men are actors in most of the actionals. In most of the transactives men are the actors while in most of the nontransactives women are the actors. This shows the higher status of men who are most of the times the actors who affect the affected (women) while the lower status of women who are most of the times the affected or the actors with no certain and known affected. On the other hand, most of the relationals are about women which show the lower status of women who have fixed and static positions.

This research can be compared with other related studies in CDA. Khosravi Nik (2000) has used Hodge and Kress's framework to show that the editors of the newspapers use the language to hide the realities and reflect the pre-planned purposes while in this research, Hodge and Kress's syntagmatic models were used to show that the use of language was to convey realities rather than concealing the facts.

Norouzi (2006) has studied the status of women in the novel 'Ræqsændegan' (Dancers). To this end, she has used Van Leeuwen's framework and shown that women are the subordinate members of the society whom men do not value. The present study using a different framework, i.e. that of Hodge and kress, has come to the same conclusion. In both studies, the texts are taken from stories, looking for facts existing in the society and reflected in the stories through language. Getting the same conclusion by different frameworks, can be a confirmation of the achieved results in both studies.

Ghanbari (2004) has analyzed and compared the discursive features in juveniles' and adults' short stories to find how and to what extent, writers use these features and conceal their ideas. She has used Van Leeuwen's framework and come to the point that discursive features in literature are not used to conceal the reality, but to reveal and emphasize it. Thus, the findings of her study is similar to this study and that of Norouzi in that it helps to show the realities reflected in the stories. The three studies can confirm the fact that language used in literature often reflects realities. This confirms the fact that genre is effective in language representation. In literature, it seems that, language is used to reveal realities, while in politics it is used to hide realities. Besides Khosravi Nik, Yarmohammadi and Rashidi (2003) have shown this fact too. Using Hodge and Kress's framework, they have shown that there exists concealment in the texts of political groups.

\section{Conclusion}

By studying the analyses of the stated discursive sentences in these short stories, it is possible to answer the research questions.

1- Do men and women have the same social status as reflected in their languages in these stories?

No, they do not. After the languages of men and women were studied in nine short stories of Bozorg Alavi based on Hodeg and Kress's syntagmatic models, it was revealed that men and women have different social status. The way that this difference can be understood is explained with regard to the answer to question 2 below.

2- If the answer to the previous question is negative, how this difference can be recognized linguistically?

If an actional is used for the man while a relational for the woman, this shows that the man has higher status than the woman does since he is the actor while the woman has a static and fixed position. As seen in the analysis of the stories, men are most of the times the actors of the actionals and especially in the transactives, i.e. men are the actors and 
women are the affected. While women are actors in fewer non-transactive sentences which show that they are actors who can not affect men but the actions affect themselves. This shows women's lower status in comparison with men who are actors in more sentences and even when they are actors, they affect women. In addition, it has been revealed that most of the relationals are about women while few are about men. This shows that women are in lower position as they have static and fixed status while men do not. Therefore, syntagmatic models lead to understanding of the status of men and women.

\section{References}

Agha Golzadeh, F. (2007). Tahlil-e gofteman-e ?enteghadi (critical discourse analysis). Tehran: Sherkate Entesharate Elmi va Farhangi.

Alavi, B. (1381). Chamadan (suitcase). Tehran: Negah.

Alavi, B. (1385). Gilehmard. Tehran: Negah.

Benoit, W. and Henson, J. (2009). President Bush's image repair discourse on Hurricane Katrina. Public Relations Review, 35(1): 40- 46.

Boutain, D. (1999). Critical language and discourse study: Their transformative relevance for critical nursing inquiry. Advances in Nursing Science, 21: 1-8.

Brantmier, C. (2003). Does gender make a difference? Passage content and comprehension in second language reading. Reading in a Foreign Language, 715(1):267-289.

Collins, C. (1999). The pragmatics of emancipation: A critical review of the work of Michael Huspek. Pragmatics, 25(6): 791-817.

Davatgarzadeh, G. (2007). The representation of social actors in Interchange Third Edition Series. Unpublished M.A. Thesis, Shiraz: Shiraz University.

Deghat, S. (2009). Critical discourse analysis of 2008 presidential campaign speech of democratic candidates with respect to their gender and race. Unpublished M.A. Thesis, Shiraz: Shiraz University.

Dellinger, B. (1995). Critical discourse analysis. Retrieved from: http://users.utu.fi/ bredelli/cda.html.

Easter, M. (2008). Freedom in speech: Freedom and liberty in U.S. presidential campaign discourse, $1952-2004$.

Poetics, 36(4): 265-286.

Fairclough, N. (1993). Critical discourse analysis: The critical study of language. London: Longman.

Fouziyeh, F. (2004). The comparison of critical discourse analysis of children and adult's short stories. Unpublished M.A. Thesis, Shiraz: Shiraz University.

Galasiski, S and Marley, C. (1998). Agency in foreign news: a linguistic complement of a content analytical study. Uk: University of Wolverhampton.

Ghanbari, L. (2004). A comparative study of juveniles' and adults' contemporary short stories within the framework of critical discourse analysis. Unpublished M.A. Thesis, Shiraz: Shiraz University.

Hawes et al. (1996). Actional and relational verbs in newspaper editorials. Retrieved September 11, 2010, from http://www.thefreelibrary.com/Actional+and+Relational+verbs+in+newspaper+editorials.-a092913073.

Hobson, H. (2003). A discussion of representation of masculinity and femininity in baden-powell's 1919 handbooks for scouts and guides using the frameworks of theo van leeuwen, within the tradition of critical discourse analysis.

Retrieved September 11, 2010, from http://www.lancs.ac.uk/fss/courses/ling/ling201/res/diss/hobson.pdf.

Hodge, R \& Kress, G.(1996). Language as ideology. Great Britain: Redwood books.

Khosravi Nik, M.(2000). The relationship between ideological structures and discursive structure of editorials and commentaries in a selected sample of iranian daily newspapers; a critical discourse perspective. Unpublished M.A. Thesis, Shiraz: Shiraz University.

Li, G. (2010). Transitivity and lexical cohesion: press representations of a political disaster and its actors. Pragmatics, 42(12): 3444-3458.

Mazid, B. (2009). date-palms, language and the power of knowledge: an analysis of a fable from Kalila and Dimna. Pragmatics, 4 1(12): 2515-2534.

Mohasel Bashough, M. (2003). A critical and functional discourse analysis of elt textbooks a need for empancipation. Unpublished M.A. Thesis, Tehran: Alzahra University.

Norouzi, F. (2006). The representation of women characteristics in narrative; texts case study on novel 'Dancers'. Unpublished M.A. Thesis, Shiraz: Shiraz University.

Smith, R. (2002). Young children's interpretations of gender from visual text and narrative. Linguistics and Education, 7(4): 303-325.

Van Dijk, T.A. (1998). Critical discourse analysis. Retrieved December 26, 2008, from

http://www.hum.uva.nl/ teun/cda.htm

Yarmohammadi, L. (1385). ?ertebatat? aez moenzoer-e gofteman shenasi-ye ?enteqadi (communications from critical discourse perspective). Tehran: Hermes.

Yarmohammadi, L. (1383). Gofteman shenasi-ye rayej va ?enteqadi (common and critical discourse). Tehran: Hermes. Yarmohammadi, L., and Rashidi, N. (2003). Pæzhuheshi dær mizan-e serahæt ya pushidegi-ye pæyam dær gozideh sær mæqalehe-ye ruznameha-ye iran: rabete-ee bein-e saxtarha-ye gofteman mædar væ saxtarha-ye zirbæna-ee fekri?ejtema-ee (A research in the amount of explicitness and concealment of the message in the selection of Iranian newspaper's editorials: a relationship between discursive structures and social underlying ideologies). Name-ye Farhoeng, 47(12): 63-75. 